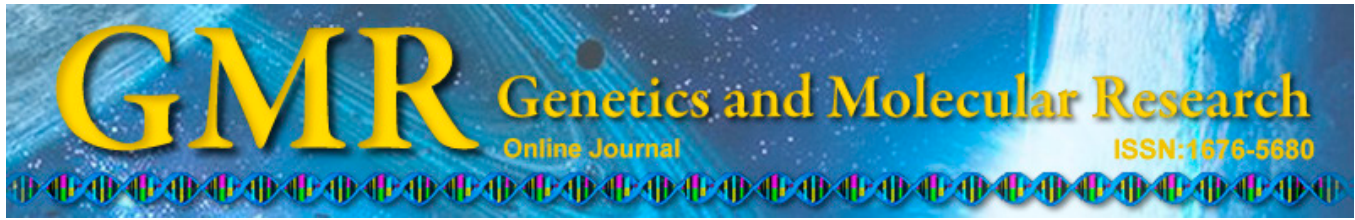

\title{
Detection of Toxoplasma gondii DNA in Brazilian oysters (Crassostrea rhizophorae)
}

L.A. Ribeiro ${ }^{1}$, L.K.N.S.S. Santos ${ }^{2}$, P.A. Brito Jr. ${ }^{2}$, B.M. Maciel $^{3}$, A.V. Da Silva ${ }^{4}$ and G.R. Albuquerque ${ }^{5}$

${ }^{1}$ Programa de Pós-Graduação em Ciência Animal, Universidade Estadual de Santa Cruz, Ilhéus, BA, Brasil

${ }^{2}$ Graduação em Medicina Veterinária, Universidade Estadual de Santa Cruz, Ilhéus, BA, Brasil

${ }^{3}$ Departamento de Ciências Biológicas, Universidade Estadual de Santa Cruz, Ilhéus, BA, Brasil ${ }^{4}$ Departamento de Ciências Biológicas, Universidade Estadual de Feira de Santana, Feira de Santana, BA, Brasil ${ }^{5}$ Departamento de Ciências Agrárias e Ambientais, Universidade Estadual de Santa Cruz, Ilhéus, BA, Brasil

Corresponding author: G.R. Albuquerque

E-mail: gralbu@uesc.br

Genet. Mol. Res. 14 (2): 4658-4665 (2015)

Received Juçy 25, 2014

Accepted December 11, 2014

Published May 4, 2015

DOI http://dx.doi.org/10.4238/2015.May.4.25

ABSTRACT. The aim of this study was to detect evidence of Toxoplasma gondii using polymerase chain reaction (PCR)-based techniques in oysters (Crassostrea rhizophorae) obtained from the southern coastal region of Bahia, Brazil. A total of 624 oysters were collected, and the gills and digestive glands were dissected. Each tissue sample was separated into pools containing tissues (of the same type) from three animals, leading to a total of 416 experimental samples for analysis (208 samples each from the gills and digestive glands). Molecular analysis using PCR-based detection of the T. gondii AF 146527 repetitive fragment yielded negative results for all samples. However, when nested-PCR was used for detection of the T. gondii 
SAG-1 gene, 17 samples were positive, with the gills being the tissue with maximal detection of the parasite. These positive results were confirmed by sample sequencing. It is therefore suggested that $C$. rhizophorae oysters are capable of filtering and retaining $T$. gondii oocysts in their tissue. This represents a risk to public health because they are traditionally ingested in natura.

Key words: Bivalve mollusks; Oyster contamination; $S A G-1$; Toxoplasmosis

\section{INTRODUCTION}

Toxoplasma gondii, a protozoan of high zoonotic importance, utilizes felids as its definitive host. Felids are the only animals capable of eliminating oocysts through their feces, whereas other homeothermic animals are considered to be intermediate hosts (Dubey, 2010). For immunologically healthy humans, the parasite infection is generally asymptomatic and presents influenza-like symptoms (Frenkel, 1990; Tenter et al., 2000). The most serious outcome of infection is seen in women who are infected for the first time during pregnancy, where infection can trigger fetal abnormalities and spontaneous abortion (Dubey, 2010), and in immunosuppressed individuals, where it may be lethal (Dubey, 2004).

Homeothermic animals that can be infected by the parasite include several species of marine mammals such as seals, sea lions, dolphins (Dubey et al., 2003), and sea otters (Conrad et al., 2005). It is believed that infection at sea occurs through the ingestion of sporulated oocysts (Conrad et al., 2005); these oocysts are transported in water from sewer sand storm drains and via rainwater runoff (Cole et al., 2000; Miller et al., 2002; Fayer et al., 2004; Conrad et al., 2005). Shoals and bays near urban centers are the areas that are primarily exposed to the parasite (Miller et al., 2002), due to the increased fecal pollution in these areas.

Oocysts are considered to be resistant to the environment, are small (11-13 $\mu \mathrm{m})$, and possess the ability to sporulate in water and become infectious to their hosts, surviving for a period of up to 6 months in seawater (Lindsay et al., 2003). Ingestion of a single oocyst is sufficient for the infection of animals such as pigs and mice (Dubey, 2004). Human infection caused by oocyst ingestion is usually more severe than that caused by the ingestion of tissue cysts, regardless of the dose (Jones and Dubey, 2010).

Bivalve mollusks, although not homeothermic, can act as a host carrier for T. gondii oocysts (Lindsay et al., 2004; Conrad et al., 2005). These animals utilize a filter-feeding process (Fayer et al., 2003, 2004), leading to the ingestion of waterborne pathogens from the environment; these pathogens are then stored in their tissues (Robertson, 2007; Leal and Franco, 2008).

T. gondii was detected in Mytilus shellfish under natural conditions in California (Miller et al., 2008) and in oysters (Crassostrea gigas) in a cultivation system in Lago di Varano, Southern Italy (Putignani et al., 2011). In Brazil, the parasite was identified in C. rhizophorae oysters that were destined for sale and consumption in the fish markets in São Paulo (Esmerini et al., 2010).

The Brazilian coastal region is characterized by the presence of extensive mangroves, and, in these areas, oysters are highly regarded both for their taste as well as their nutritional value (Nascimento and Pereira, 2004), with the C. rhizophorae mollusk being of greatest eco- 
nomic interest, especially in Bahia (Nascimento et al., 1986; Boehs et al., 2010). The principal threat that these oysters pose is via ingestion because these are traditionally ingested in natura, representing a risk to public health. In this study, the presence of $T$. gondii DNA was investigated in C. rhizophorae oysters from the southern coast of Bahia, Brazil, using polymerase chain reaction (PCR) and nested-PCR techniques.

\section{MATERIAL AND METHODS}

\section{Sample collection}

The oyster (C. rhizophorae) samples used in this study were acquired on a monthly basis from two cities on the southern coast of Bahia: Ilhéus, with oysters harvested from the natural beds of the Cachoeira River estuary; and from the Porto Campo region in Camamu Bay, where samples were obtained from the longline cultivation system. Three hundred and twelve oysters were collected from each city (624 unique tissue samples in total). In the laboratory, the outer surfaces of the shells were washed with distilled water, and the gills and digestive glands were removed and randomly separated into pools of samples (of the same type) from three animals. Each pool was analyzed as a single experimental sample; in total, there were 416 such samples, with 208 samples of each tissue type. The samples were placed in cryotubes and frozen at $-80^{\circ} \mathrm{C}$ until the DNA extraction process.

\section{DNA extraction}

The Easy-DNA extraction kit (Invitrogen, Carlsbad, CA, USA) was used for DNA extraction according to manufacturer guidelines, with some adaptations made to the process for breaking the oocyst wall.

Approximately $1 \mathrm{~g}$ sample from each tissue was used for DNA extraction. Samples were mixed with a solution containing $400 \mu \mathrm{L}$ TE buffer (Tris-HCl EDTA, provided in the kit) and $1 \mathrm{~g}$ glass beads, and homogenized in a vortex for $2 \mathrm{~min}$. Subsequently, samples were centrifuged for $10 \mathrm{~min}$ at $21,913 \mathrm{~g}$. The resulting supernatant was transferred to a $2.0-\mathrm{mL}$ microtube. For maximal extraction, an additional $150 \mu \mathrm{L}$ TE buffer was added to the original microtube containing the glass beads and homogenized and centrifuged again as previously described. Next, $350 \mu \mathrm{L}$ Solution A from the Easy-DNA extraction kit (Invitrogen) was added; the mixture was homogenized, and thermal shocks were administered (five cycles of freezing in liquid nitrogen for $15 \mathrm{~s}$ and thawing at $92^{\circ} \mathrm{C}$ for $\left.2 \mathrm{~min}\right)$. Proteinase $\mathrm{K}(5 \mu \mathrm{L})$ was added and the tubes were incubated in a water bath at $65^{\circ} \mathrm{C}$ for $1 \mathrm{~h}$, followed by addition of $150 \mu \mathrm{L}$ Solution B. For positive control samples, oocysts from $T$. gondii were added to the oyster tissues and the extraction was performed as described above.

The extracted DNA was quantified using a NanoDrop (Thermo Scientific, Walther, MA, USA) spectrophotometer, and the purity was checked by estimating the $\mathrm{A}_{260} / \mathrm{A}_{280}$ ratio. The samples that showed concentrations above $1000 \mathrm{ng} / \mu \mathrm{L}$ were diluted to $100 \mathrm{ng} / \mu \mathrm{L}$ for further analysis.

\section{PCR amplification}

PCR was performed using primers T4 (5'-CGC TGC AGG GAG GAA GAC GAA 
AGT TG-3') and T5 (5'-CGC TGC AGA CAC AGT GCA TCT GGA TT-3') that amplified a 529-bp T. gondii repetitive sequence (GenBank accession No. AF 146527) (Homan et al., 2000). The reaction mixture included $5 \mu \mathrm{L}$ extracted DNA as the template, and a $20-\mu \mathrm{L}$ mixture [0.2 $\mathrm{mM}$ of each primer, $0.2 \mathrm{mM}$ dNTPs (Invitrogen), $1 \mathrm{X}$ PCR buffer, $2.5 \mathrm{mM} \mathrm{MgCl}$, and $2 \mathrm{U}$ Taq DNA polymerase (Invitrogen)]. The PCR program for amplification of parasite DNA was as follows: $5 \mathrm{~min}$ at $94^{\circ} \mathrm{C}$ for initial denaturation; 33 cycles each of $1 \mathrm{~min}$ at $94^{\circ} \mathrm{C}$ for denaturation, $1 \mathrm{~min}$ at $60^{\circ} \mathrm{C}$ for annealing, and $1 \mathrm{~min}$ at $72^{\circ} \mathrm{C}$ for extension; and extension for $10 \mathrm{~min}$ at $72^{\circ} \mathrm{C}$. The PCR products were subjected to electrophoresis on a $1 \%$ agarose gel and stained with SYBR ${ }^{\circledR}$ Safe DNA Gel Stain (Life Technologies, Carlsbad, CA, USA). DNA extracted from oyster tissue to which had been added T. gondii RH strain tachysoites was used as a positive control. For the negative control, ultrapure water was used. Positive and negative controls were included in each test.

\section{Nested PCR amplification}

Nested PCR for the amplification of a 329-bp region of the $S A G-1$ gene of $T$. gondii was performed using the primary primers F1: 5'-GTT CTA ACC ACG CAC CCT GAG-3' and R1: 5'-AAG AGT GGG AGG CTC TGT GA-3'; and the secondary primers F2: 5'-CAA TGT GCA CCT GTA GGA AGC-3' and R2: 5'-GTG GTT CTC CGT CGG TGT GAG-3'. The first round of PCR was performed with $5 \mu \mathrm{L}$ extracted DNA and a $20-\mu \mathrm{L}$ reaction mixture $[0.25$ $\mathrm{mM}$ of each primer, $0.2 \mathrm{mM}$ dNTP (Invitrogen), $1 \mathrm{X}$ PCR buffer, $3.0 \mathrm{mM} \mathrm{MgCl}$, and 1.25 U Taq DNA polymerase (Invitrogen)]. Parasite DNA amplification was performed under the following conditions: $5 \mathrm{~min}$ at $94^{\circ} \mathrm{C}$ for denaturation; 35 cycles each of $1 \mathrm{~min}$ at $94^{\circ} \mathrm{C}$ for denaturation, $1 \mathrm{~min}$ at $58^{\circ} \mathrm{C}$ for annealing, and $1 \mathrm{~min}$ at $72^{\circ} \mathrm{C}$ for extension; and a final extension at $72^{\circ} \mathrm{C}$ for $10 \mathrm{~min}$. A $2-\mu \mathrm{L}$ aliquot of the PCR product was used in the nested PCR performed using the secondary primers. The second round of PCR was carried out under the same cycling conditions as the first. The PCR products were subjected to electrophoresis on a $1 \%$ agarose gel, and stained with $\mathrm{SYBR}^{\circledR}$ Safe DNA Gel Stain.

\section{Sequencing}

Samples considered positive on the basis of the $S A G-1$ nested PCR results were subjected to a purification process using the PureLink ${ }^{\circledR}$-Quick Gel Extraction kit and PCR Purification kit (Invitrogen) and were sent to the Ludwig Biotec Company (Porto Alegre, RS, Brazil) for sequencing in both directions using internal primers. The sequencing results were analyzed and subjected to a BLAST (http://blast.ncbi.nlm.nih.gov/Blast.cgi) for identification.

\section{Statistical analysis}

The relative frequencies of positive samples from the cities from which the samples were obtained (Ilhéus and Camamu) were compared with the $\chi^{2}$ Pearson test using the EpiInfo 7 software (Dean et al., 2011), and the incidence of detection of $T$. gondii from the oyster organs (gills and digestive glands) was compared with the McNemar exact test using the BioEstat 5 software (Ayres et al., 2007). In all analyzes, significant $P$ values were considered when less than 0.05 (Ayres et al., 2007). 


\section{RESULTS}

The method for extracting DNA from oyster tissue, as described in this study, was effective for the detection of $T$. gondii, as described below. On average, DNA concentrations of $1736.2 \mathrm{ng} / \mu \mathrm{L}$ with an $\mathrm{A}_{260} / \mathrm{A}_{280}$ ratio ranging from 1.80 to 2.08 were obtained.

All 624 oyster samples from the southern coast of Bahia (Ilhéus and Camamu) were considered negative by molecular analysis for the $T$. gondii repetitive sequence AF 146527 . However, using nested PCR for the $S A G-1$ gene, 17 (8.1\%) samples yielded positive results, showing a corresponding amplicon at the expected size of $392 \mathrm{bp}$ for DNA of tissue samples from both the gills and digestive glands.

For Ilhéus, seven (6.7\%) samples yielded positive results with nested PCR; four $(57.1 \%)$ of these were from pools of gill tissue and three $(42.9 \%)$ were from the digestive glands. For Camamu Bay, 10 (9.6\%) samples were positive; nine (90\%) were obtained from the gills and only one was from the digestive gland (Figure 1). There was no significant difference between the cities in terms of incidence $(\mathrm{P}=0.31)$. However, the incidence of detection differed with respect to the tissue studied $(\mathrm{P}=0.02)$, with a higher frequency of positive results obtained for gill samples.

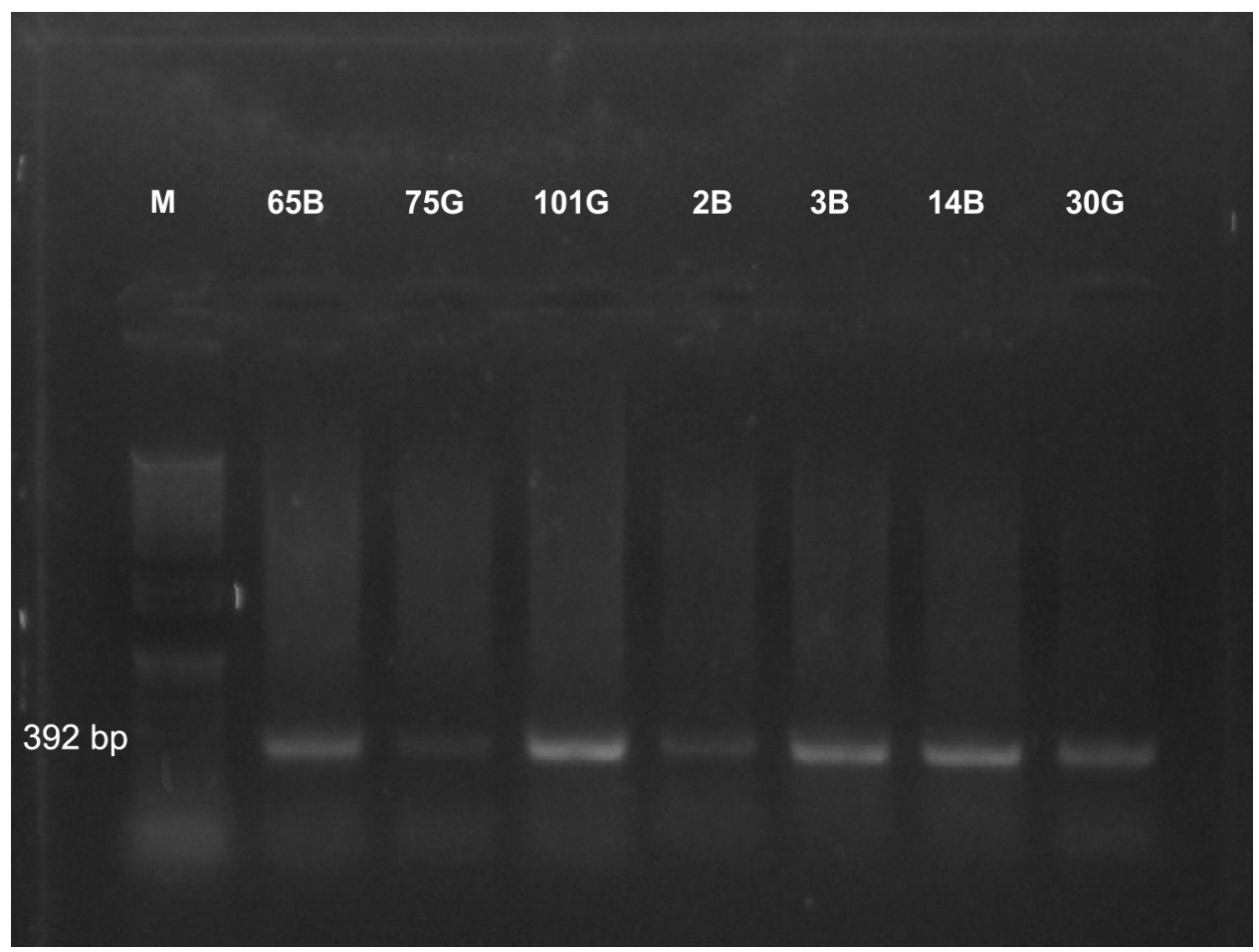

Figure 1. Electropherogram showing amplification of the Toxoplasma gondii $S A G-1$ gene using nested polymerase chain reaction (PCR). The amplified product is shown at 329 bp. Lane $M=$ molecular weight marker; lane $65 B=$ Ilhéus's gills samples; lane $75 G$ and $101 G=$ Ilhéus's digestive gland samples; lane $2 B, 3 B$ and $14 B$ = Camamu's gills samples; lane $30 G=$ Camamu's digestive gland samples. Resolution of PCR products was performed on a $1 \%$ agarose gel. 
The 17 samples identified as positive using the nested PCR technique were confirmed by sequencing and showed between 99 and $100 \%$ identity with the $S A G-1$ gene sequences of T. gondii available in the National Center for Biotechnology Information database (accession Nos. GQ253073.1, GQ253086.1, GQ253075.1, and GQ253074.1).

\section{DISCUSSION}

To our knowledge, this is the first study to describe the detection of $T$. gondii DNA in tissue samples of oysters obtained from the northeastern coast of Brazil.

Detecting oocysts in environmental samples is considered to be a scientific challenge because of the technical limitations of parasite detection. Although the nested PCR technique is sufficiently sensitive to identify $T$. gondii, the resistant form of this parasite (oocysts) in the environment is difficult to detect, since it has an extremely tough wall that can interfere with DNA extraction.

According to Dumètre and Dardé (2003), various techniques can be used to break the oocyst wall, including in vitro encystation, digestion with proteinase $\mathrm{K}$, grinding with glass beads, and the use of thermal shocks, but the protocols are not standardized with respect to the temperature and the number of freeze/thaw cycles to be used. The current study employed glass beads, thermal shock, and proteinase $\mathrm{K}$ addition, which is similar to the process used by Esmerini et al. (2010), except that glass beads were not used in that study. Putignani et al. (2011) opted to use only thermal shock in their study. These differences in DNA extraction procedures may influence the results obtained by different researchers.

In this study, an $8.1 \%$ positive detection rate was obtained for $T$. gondii, a result higher than that obtained in the study performed in Brazil by Esmerini et al. (2010), who reported a $3.3 \%$ positive rate. Several factors might be related to this higher detection rate, including the tissue used and the sites from where the samples were collected. In this experiment, the oysters were dissected and only the gills and digestive glands were used, because these are the sites from which parasites are detected most often (Robertson, 2007; Leal and Franco, 2008). In the study by Esmerini et al. (2010), the entire oyster was used, and this might have lowered the sensitivity of detection. The environment in Southern Bahia is characterized by the Atlantic Forest, with a high relative humidity that is favorable for oocysts in the environment. The climate on the southern coast of Bahia is tropically humid, and characterized by high rainfall of up to $60 \mathrm{~mm}$ in the dry months, and of around $1400 \mathrm{~mm}$ annually (Klumpp et al., 2002). This, together with the low levels of basic sanitation in the region, may be predisposing factors for increased parasite incidence. Another important factor is the presence of various species of wild felids (Moura, 2003), together with the large quantity of domestic cats wandering throughout the region.

Positive results were obtained for the oysters in the months of April, August, and September in Ilhéus and in April, June, and August in Camamu. This can be explained by the higher rainfall at that time of the year, with rainfall of nearly $300 \mathrm{~mm}$ in August in Ilhéus and rainfall greater than $150 \mathrm{~mm}$ in April in Camamu, reaching $300 \mathrm{~mm}$ in June 2012 (INMET). It is believed that the spread of oocyst contamination from land to the marine coast arises mainly as a result of rain water runoff, which transports waste and the feces of infected cats, as described by Cole et al. (2000) and Conrad et al. (2005). According to Miller et al. (2002), shoals and bays close to urban centers are the areas that are most exposed to T. gondii because of the greater fecal pollution in these areas. This study identified $T$. gondii in oysters from 
bays (estuaries), which are found close to the coastal populations, where all the waste (human/ animal) is dumped into the environment without any kind of treatment.

The highest prevalence of positive detection of $T$. gondii was found in samples from gill tissues (76.5\%), which is similar to the results from studies by Esmerini et al. (2010) and Putignani et al. (2011). There is evidence that these tissues are ideal for the detection of the parasite (Potasman et al., 2002; Arkush et al., 2003; Putignani et al. 2011), because oysters, by means of their filter-feeding mechanism, can ingest approximately five liters of water per hour and therefore light particles like T. gondii oocysts are retained in the gills (Ruppert and Barnes, 1996; Robertson, 2007; Leal and Franco, 2008).

According to Sande et al. (2010) and Brandão et al. (2013), both the Cachoeira River estuary and Camamu Bay are considered suitable areas for extracting mollusks, which are used as a source of food for the coastal population, as well as for sale during the high season, as summer. Bivalve mollusks reflect the conditions in which they live and are considered bioindicators of environmental contamination (Miller et al., 2002). The estuarine environments in the cities of Ilhéus and Camamu were considered to be contaminated with T. gondii oocysts because oysters from both these environments were positive for the parasite.

The parasite $T$. gondii has a large worldwide distribution, and in Brazil there is also a high prevalence of infection by the parasite in humans and animals. The reported cases of toxoplasmosis in Brazil are primarily associated with the consumption of undercooked or raw meat and through ingestion of oocysts in contaminated food and water (Dubey et al., 2012). Dubey (2004) suggested that oocyst infections, regardless of the dose, are clinically more serious in humans than infections acquired through tissue cysts. In the current study, we could not determine the viability of the parasite, but it is widely known that the oocysts can sporulate in seawater and become infectious for a period of up to 6 months in water (Lindsay et al., 2003). In the region of this study, oysters are generally eaten in natura, and it is known that even a single oocyst of $T$. gondii can cause infection. Thus, it can be assumed that the coastal population and individuals who ingest oysters purchased from the fish market are at risk of acquiring toxoplasmosis.

\section{ACKNOWLEDGMENTS}

The authors thank Dr. João Luis Garcia for Toxoplasma gondii oocysts. We also thank Fundação de Amparo à Pesquisa do Estado da Bahia (FAPESB) and Conselho Nacional de Desenvolvimento Científico e Tecnológico (CNPq) for financial support. We also thank CNPq for awarding a fellowship to G.R. Albuquerque.

\section{REFERENCES}

Arkush KD, Miller MA, Leutenegger CM, Gardner IA, et al. (2003). Molecular and bioassay-based detection of Toxoplasma gondii oocyst uptake by mussels (Mytilus galloprovincialis). Int. J. Parasitol. 33: 1087-1097.

Ayres M, Ayres Jr M, Ayres DL and Santos AS (2007). BioEstat 5.0. Aplicações estatísticas nas áreas das ciências biológicas e médicas. Instituto de Desenvolvimento Sustentável Mamirauá, Belém.

Boehs G, Villalba A, Ceuta LO and Luz JR (2010). Parasites of three commercially exploited bivalve mollusc species of the estuarine region of the Cachoeira river (Ilhéus, Bahia, Brazil). J. Invertebr. Pathol. 103: 43-47.

Brandão RP, Boehs G, Sabry RC, Ceuta LO, et al. (2013). Perkinsus sp. infecting oyster Crassostrea rhizophorae (Guilding, 1828) on the coast of Bahia, Brazil. J. Invertebr. Pathol. 112: 138-141.

Cole RA, Lindsay DS, Howe DK, Roderick CL, et al. (2000). Biological and molecular characterizations of Toxoplasma gondii strains obtained from southern otters (Enhydra lutris nereis). J. Parasitol. 86: 526-530. 
Conrad PA, Miller MA, Kreuder C, James ER, et al. (2005). Transmission of Toxoplasma: clues from the study of sea otters as sentinels of Toxoplasma gondii flow into the marine environment. Int. J. Parasitol. 35: 1155-1168.

Dean AG, Arner TG, Sunki GG, Friedman R, et al. (2011). Epi Info ${ }^{\mathrm{TM}}$, a database and statistics Program for Public Health Professionals. CDC, Atlanta.

Dubey JP (2004). Toxoplasmosis - a waterborne zoonosis. Vet. Parasitol. 126: 57-72.

Dubey JP (2010). Toxoplasmosis of animals and humans. 2nd edn. CRC Press, Boca Raton.

Dubey JP, Zarnke R, Thomas NJ, Wong SK, et al. (2003). Toxoplasma gondii, Neospora caninum, Sarcocystis neurona and Sarcocystis canis-like infections in marine mammals. Vet. Parasitol. 116: 275-296.

Dubey JP, Lago EG, Gennari SM, Su C, et al. (2012). Toxoplasmosis in humans and animals in Brazil: high prevalence, high burden of disease, and epidemiology. Parasitology 139: 1375-1424.

Dumètre A and Dardé ML (2003). How to detect Toxoplasma gondii oocysts in environmental samples? FEMS Microbiol. Rev. 27: 651-661.

Esmerini PO, Gennari SM and Pena HF (2010). Analysis of marine bivalve shellfish from the fish market in Santos city, Sao Paulo state, Brazil, for Toxoplasma gondii. Vet. Parasitol. 170: 8-13.

Fayer R, Trout JM, Lewis EJ, Santin M, et al. (2003). Contamination of Atlantic coast commercial shellfish with Cryptosporidium. Parasitol. Res. 89: 141-145.

Fayer R, Dubey JP and Lindsay DS (2004). Zoonotic protozoa: from land to sea. Trends Parasitol. 20: 531-536.

Frenkel JK (1990). Toxoplasmosis in human beings. J. Am. Vet. Med. Assoc. 196: 240-248.

Homan WL, Vercammen M, De Braekeleer J and Verschueren H (2000). Identification of a 200- to 300-fold repetitive 529 bp DNA fragment in Toxoplasma gondii, and its use for diagnostic and quantitative PCR. Int. J. Parasitol. 30: 69-75.

INMET (Instituto Nacional de Meteorologia). Available at [http://www.inmet.gov.br/portal]. Accessed June 12, 2013.

Jones JL and Dubey JP (2010). Waterborne toxoplasmosis - Recent developments. Exp. Parasitol. 124: 10-25.

Klumpp A, Bauer BK, Gerstein CF and Menezes M (2002). Variation of nutrient and metal concentration in aquatic macrophytes along the Rio Cachoeira in Bahia (Brazil). Environ. Int. 28: 165-171.

Leal DAG and Franco RMB (2008). Moluscos Bivalves Destinados ao Consumo Humano como Vetores de Protozoários Patogênicos: Metodologia de Detecção e Normas de Controle. Rev. Panam. Infectol. 10: 48-57.

Lindsay DS, Collins MV, Mitchell SM, Cole RA, et al. (2003). Sporulation and survival of Toxoplasma gondii oocysts in seawater. J. Eukaryot. Microbiol. 50 (Suppl): 687-688.

Lindsay SS, Collins MV, Mitchell MM, Wetch CN, et al. (2004). Survival of Toxoplasma gondii oocysts in eastern oysters (Crassostrea virginica). J. Parasitol. 90: 1054-1057.

Miller MA, Gardner IA, Kreuder C, Paradies DM, et al. (2002). Coastal freshwater runoff is a risk factor for Toxoplasma gondii infection of southern sea otters (Enhydra lutris nereis). Int. J. Parasitol. 32: 997-1006.

Miller MA, Miller WA, Conrad PA, James ER, et al. (2008). Type X Toxoplasma gondii in a wild mussel and terrestrial carnivores from coastal California: new linkages between terrestrial mammals, runoff and toxoplasmosis of sea otters. Int. J. Parasitol. 38: 1319-1328.

Moura RT (2003). Distribuição e ocorrência de mamíferos na Mata Atlântica do sul da Bahia. Available at [http:// programas.inema.ba.gov.br/sigbiota/iesb/Documentos/mamiferos.pdf]. Accessed December 12, 2013.

Nascimento IA and Pereira SA (2004). Cultivo da ostra de mangue Crassostrea rhizophorae (Guilding 1828). In: Aquicultura: Experiências Brasileiras (Poli CR, Poli AT, Andreatta E and Beltrame E, eds.). Multitarefa, Florianópolis, 267-288.

Nascimento IA, Smth DH, Kern F II and Pereira SA (1986). Pathological findings in Crassostrea rhizophorae from Todos os Santos Bay, Bahia, Brazil. J. Invertebr. Pathol. 47: 340-349.

Potasman I, Paz A and Odeh M (2002). Infectious outbreaks associated with bivalve shellfish consumption: a worldwide perspective. Clin. Infect. Dis. 15: 921-928.

Putignani L, Mancinelli L, Del Chierico F, Menichella D, et al. (2011). Investigation of Toxoplasma gondii presence in farmed shellfish by nested-PCR and real-time PCR fluorescent amplicon generation assay (FLAG). Exp. Parasitol. 127: 409-417.

Robertson LJ (2007). The potential for marine bivalve shellfish to act as transmission vehicles for outbreaks of protozoan infections in humans: a review. Int. J. Food Microbiol. 120: 201-216.

Ruppert EE and Barnes RD (1996). Zoologia dos Invertebrados. 6th edn. Saunders College Publishing/Editora Roca Ltda., São Paulo.

Sande D, Melo TA, Oliveira GSA, Barreto L, et al. (2010). Prospecção de moluscos bivalves no estudo da poluição dos rios Cachoeira e Santana em Ilhéus, Bahia, Brasil. Braz. J. Vet. Res. Anim. Sci. 47: 190-196.

Tenter AM, Heckeroth AR and Weiss LM (2000). Toxoplasma gondii: from animals to humans. Int. J. Parasitol. 30: $1217-1258$. 